\title{
Agro-based Waste Products as a Substrate for Mass Production of Trichoderma spp.
}

\author{
Sobita Simon \\ Department of Plant Protection \\ Allahabad Agricultural Institute Deemed University \\ Allahabad 211007, India \\ E-mail: Sobitasimon@reddifmail .com \\ Anamika \\ Department of Plant Protection \\ Allahabad Agricultural Institute Deemed University \\ Allahabad 211007, India \\ E-mail: Anamika_bhu01@rediffmail.com
}

Received: December 28, 2010

Accepted: January 21, 2011 Published: December 1, 2011

doi:10.5539/jas.v3n4p168

URL: http://dx.doi.org/10.5539/jas.v3n4p168

\begin{abstract}
Various agricultural by products such as vegetable wastes, fruit wastes, crop wastes, FYM and Poultry manure were evaluated for mass production of Trichoderma viride and Trichoderma harzianum. Among the substrates used wastes of brinjal, banana, papaya, guava, spinach, sugarcane, tealeaves and pea husk of solid and liquid was found supported maximum spore production insolid and liquid for the growth of Trichoderma harzianum and Trichoderma viride as compared with wastes of carrot, cucumber, potato, radish, cabbage, orange peel, wheat bran, FYM and Poultry manure.
\end{abstract}

Keywords: Mass production, Agricultural wastes products, Trichoderma spp.

\section{Introduction}

Trichoderma is widely used as bio-control agent against several root pathogenic fungi throughout the world (Chet etal, (1979) Elad etal. (1980), Sivan et al. 1984). Trichoderma spp. is free living fungi that are highly interactive in root, soil foliar and environments. It has been known for many years that they produce a wide range of antibiotic substances and they paralyze other fungi (Tayler and Farncis, 1998). They can also compete for key exudates from seeds that stimulates the germination of propagales of plant pathogenic fungi in soil (Howel 2002) and more generally compete with soil micro-organisms for nutrient and space (Elad 1996). Trichoderma spp. was identified as potential antagonists of Rhizoctonia solani and Macrophomina phaseolina (Singh 1994).

Antifungal metabolites of Trichoderma have been grouped by Ghisalberti and Sivasithamparam, 1991. Trichoderma spp. are known to produce mycolytic enzymes such as $\beta-1,3$, glucanasa, $\beta-1,4$ endo-glucanase, chitinase and protease. These enzymes play an important role in the degradation of chitin which is the structural component of the target pathogens and herbivorous insects and consequent myco-parasitism (Harman et al., 1993). Baker and Dickman (1993) found high enzyme activity in susceptible pathogen. Genetic improvement of Trichoderma as a biological control agent using induced mutagensesis has been successfully attempted for fungicidal resistance (Papavizas et al., 1982), antibiotic production (Faull et al, 1994) and enzyme secretion (Witkowska and Bien 1991). Metcalf et al., (2001) studied the disease control potential of Trichoderma spp. For biological control of onion white root-rot disease caused by Sclerotium capivorum. The mode of action in environmental condition of favourable growth and establishment of Trichoderma spp. and mechanism of antagonize and parasitize to other fungi was reported by Kulling et al., (2000). Howell et al., (2000) examined 
that seed treatment with Trichoderma virens stimulates defense response, as indicated by the synthesis of terpenoides in cotton roots and the role of terpenoide compounds is in disease control.

Lin et al., (1994) reported that Tricholin, a ribosome inactivating protein isolated from the culture broth of $T$. viride and they concluded Tricholin is an effective inhibitor of protein synthesis. Cherif and Benhamou (1980) reported a strain of Trichoderma has the ability to reproduce chitinases and inhibits growth of F. oxysporum.

Mass production of Trichoderma required to find out suitable media on large amount of Trichoderma biomass is required therefore, the first step for the mass production of any bio-control agent is to identify the suitable substrates, which should be comparatively cheap, stable and easily available with in a short period of time. The type and form of substrate i.e. broth and solid may also vary according to the specific purpose for which bio-control agent biomass is required.

The quality of a microbial bio-protectant is dependent on the propagate density in the biomass and its ability to survive processing (Harman et al, 1991). Production of adequate quantities of good quality inoculum is an essential component of the biocontrol programme. The production of Trichoderma may be taken up by the labour intensive and economically viable methods for relatively progressive farmers. Development of simple and reliable production system of submerged liquid fermentation for the production of blastospores, which are short lived and hydrophilic (Ramback 1989) or solid state fermentation (Roussan et al; 1988) for the production of aerial conidia. Therefore the present study was aimed to find out the suitability of various semi solid substrates and liquid media for biomass production of selected Trichoderma species.

\section{Materials and Methods}

Semisolid substrates of 50g each eighteen different agro -wastes products viz. Carrot, Cucumber, Potato, Brinjal, Banana, Papaya, Radish, Cabbage, FYM , Poultry, Guava, Spinach, Orange, Sugarcane, Tea leaves, Pea husk, Rice husk, Wheat bran were selected and wetted with $2 \%$ molasses. Each substrate was transferred to $250 \mathrm{ml}$ conical flask and put cotton cork. For broth substrate the above substrates were used @ 50g/150ml distilled water, boiled for 10 minutes and filter through mashlin cloth. The supernatant solution was collected in $250 \mathrm{ml}$ of conical flask. Further solid and liquid substrates were sterilized in autoclave at 15 psi pressure for 20 minutes. After proper sterilization both the substrates (solid and liquid) were inoculated with Trichoderma viride and Trichoderma harzianum and incubated at $27 \pm 1^{\circ} \mathrm{C}$. Observation were recorded on growth rate and colony colour at 20 days after incubation.

\section{Results and Discussion}

The data regarding growth rate and sporulation pattun of Trichoderma viride and Trichoderma harzianum are summarized in table no. 1. In case of Trichoderma viride in solid and liquid media in different substrate, it was observed that $T$. viride produced hyaline colony at first, which gradually changed to yellowish green colour is latter stage. The yellowish green colour was more prominent at later stage, Trichoderma harzianum initially produced light green colour colony further with is $24 \mathrm{hrs}$ the mycelium spread over the surface of the substrates which become dark in colour due to abundant sporulation.

The moderate sporulation was also obtained in the substrates of wheat bran was $0.79(\mathrm{~s}), 0.83(\mathrm{~L})$, in raddish $0.68(\mathrm{~S}) ; 0.84(\mathrm{~L}) \times 10^{6} \mathrm{CFU} / \mathrm{ml}$ for $T$. harzianum. In case of $T$. viride the sporulation was noted in wheat bran $0.81(\mathrm{~s}) ; 0.84(\mathrm{~L})$ and in radish $0.46(\mathrm{~s}) ; 0.69(\mathrm{~L}) \times 10^{6} \mathrm{cfu} / \mathrm{ml}$. Rama etal., (2001) also reported the best substrate of T. harzinaum, T. ressei grow better in sugarcane waste and used tea leaves, where as $T$. viride and $T$. Kaningii showed maximum growth in tea leaves + wheat bran substrate. The result of table no.1 shows that $T$. harzianum sporulation shows slow in FYM 0.27(S), 0.32(L) and rice husk 0.20(S), 0.41(L), Poultry manure 0.26(S); 0.27(L) $\mathrm{x} 10^{6} \mathrm{cfu} / \mathrm{ml}$. In case of $T$. viride the sporulation rate in FYM o.16(S); 0.19(L); rice Rusk 0.23(S); 0.37(L) and in poultry manure $0.13(\mathrm{~S}) ; 0.16(\mathrm{~L}) \times 10^{6} \mathrm{cfu} / \mathrm{ml}$ respectively.

In the present study wastage of Potato peel, Brinjal, Banana, Papaya, Guava, Spinach, Sugarcane, used Tea leaves and Pea husk medium of solid and liquid was found best for the growth of Trichoderma harzianum and Trichoderma viride isolates. Suitability of the wheat bran for the growth of Trichoderma has been reported by Lumsden and Lewis (1988) and singh (1994) and Rama etal, (2001). From the study it was clear that Trichoderma are able to grow on a wide variety of agriculture by products on both solid and liquid state and this can be useful to farmers to cultivate these fungi very easily.

\section{References}

Baker, R. \& Dickman, M.B. (1993). Bio-control with fungi. In: soil Microbiology application in Agricultural and environmental management (Edn F.B. Melting Jr.) pp 275-306. Marcel Bekker Inc. New York. 
Cherif, M. \& Benhamou, N. (1990). Cytochemical aspects of Chitin breakdown during the parasitic action of a Trichoderma sp. on Fusarium oxysporum f. sp. radicis lycopersici, Phytopathology, 180(12):1406-1414. http://dx.doi.org/10.1094/Phyto-80-1406

Chet, I., Harman, G.E. \& Baker, R. (1979). Trichodrma hamatum, its hyphal interactions with Rhizoctonia solani and Phythium spp. Microbiol. E. Col., 7:29-38.

Elad, Y., Katan, J. \& Chet, I. (1980). Physical, biological and chemical control integrated for soil borne diseases of potato. Phytopathology, 70:418-522. http://dx.doi.org/10.1094/Phyto-70-418

Elad, Y. (1996). Mechanism involved in the biological control of Botrytis cinera incited diseases. European Journal of Plant Pathology, 102:719-732. http://dx.doi.org/10.1007/BF01877146

Faull, J.L., Graeme- Cook, K.A. \& Rilkington, B.L. (1994). Production of an isonitrile antibiotic by an Uv-induced mutants of Trichoderma harzianum. Phytochemistry, 36:1273-1276.

Ghisalberti, E.L. \& K, Sivasithamparam. (1991). Antifungal antibiotics produced by Trichoderma spp. Soil biology and Biochemistry, 23:1011-1020. http://dx.doi.org/10.1016/0038-0717(91)90036-J

Harman, G.E., X. Jin, T.E. stasz, G. Peruzzaoil, A.C. Leopoid \& A.G. Taylor. (1991). Production of conidial biomass of Trichoderma harzianum for biological control. Biological control, 1:23-38. http://dx.doi.org/10.1016/1049-9644(91)90097-J

Howell, C.R. Hanson L.E., Stapanovic R.D. \& Pukhaber L.S., (2000). Induction of terpenoid synthesis in cotton and control of Rhizoctonia solani by seed treatment with Trichoderma virens. Phytopathology, 90 (3):248-252. http://dx.doi.org/10.1094/PHYTO.2000.90.3.248

Howell, C.R. (2002). Cotton seedling pre emergence damping off incited by Rhizopus oryzae and Pythium spp. and its biological control with Trichoderma spp. Phytopathology, 92: 177-180. http://dx.doi.org/10.1094/PHYTO.2002.92.2.177

Kulling, C, Mach, R.L., Lorita, M. \& Kubicek, C.P. (2000). Enzyme diffusion from Trichoderma viride, Trichoderma harzianum $\mathrm{P}_{1}$ to Rhizoctonia solani is a prereques it's for triggering of Trichoderma each 42 gene expression before mycoparasitic contact. Applied and Environmental Microbiology, 66(5):2232-2234. http://dx.doi.org/10.1128/AEM.66.5.2232-2234.2000

Lin, A., Lee, T.M. \& Rern, J.C. (1994). Tricholina new antifungal agent from Trichoderma viride and its action in biological control. Rhizoctonia solani. journal of Antibiotics, 47(7):799-805.

Lumsden, R.D. \& J.A. Lewis. (1988). Selection production, formulation and commercial use of plant disease bio-control fungi. Problems and Progress in: J.M. whipps and R.D Lumsden (Eds). Biotechnology of fungi for improving plant growth. Cambridge University Press. Combridge, pp 171-189.

Metcalf, D.A., wilsoni C.R. \& Armstrong, J. (2001). Progress toward a biological control system for onion white root rot in Tasmania. Proceedings of the second International symposium on edible Alliaceae, Adelaide, Australia. Nov.10-13. Acta Horticulture, 555, 123-127.

Papavizas, G.C., Lewis, J.A. \& Abd-El Monity T.H. (1982). Evaluation of new biotypes of Trichoderma harzianum for toleuance to benomyl and enhanced bio-control capabilities Phytopathology. 72:126-132. http://dx.doi.org/10.1094/Phyto-72-126

Rama, S.S., H.V. Singh, Puneet Singh \& Jaspal Kaur (2001). A comparison of different substrates for the mass production of Trichoderma. Ann. Pl. Protec. Sci. 9(2)248-253.

Romback. M.C. (1989). Production of Beauveria bassiana conida in submerged culture, Entomophaga, 5:45-52. http://dx.doi.org/10.1007/BF02372586

Rousson S, Rainbautt M, Lonsane B.K. (1983). Zymotics a large scale fermenter design and evaluation. Appl. Biochem. Biotechnol., 42:161-167.

Singh. R.S. (1994). Productions and formulation of bio-fungicides from selected isolates/ strain of Trichoderma species. Final Report of Research scheme. Dept Plant Pathology, PAU, Ludhiana, pp77.

Sivan, A., Elad, Y. \& Chet, I. (1984). Biologivcal control effects of a new isolate of Trichodema harzianum and Phythium aphanidermatum. Phytopathology, 74:498-501. http://dx.doi.org/10.1094/Phyto-74-498

Taylor. E. \& Francis, L. (1998). Trichoderma and Glioclandium. Phytopathology, 1:139-191.

Witkowska, D \& Bien, M. (1991). Activity in biosyntheses of extra-cellular hydrolases of Trichoderma viride mutants obtained in two-stage mutation, Accta Aliment Poland, 41:127-135. 
Table 1. Growth and sporulation of Trichoderma isolates on agro-wasted solid and liquid at 20 days after inoculation

\begin{tabular}{|c|c|c|c|c|c|c|c|c|}
\hline \multirow[t]{3}{*}{ Substrate } & \multicolumn{4}{|c|}{ T. harzianum } & \multicolumn{4}{|c|}{ T. viride } \\
\hline & \multirow[t]{2}{*}{ GR } & \multirow[t]{2}{*}{ SP } & \multicolumn{2}{|c|}{ Spore density $\left(1 \times 10^{6} \mathrm{CFU} / \mathrm{g}\right)$} & \multirow[t]{2}{*}{ GR } & \multirow[t]{2}{*}{$\mathbf{S P}$} & \multicolumn{2}{|c|}{ Spore density $\left(1 \times 10^{6} \mathrm{CFU} / \mathrm{g}\right)$} \\
\hline & & & Solid & Liquid & & & Solid & Liquid \\
\hline Carrot peel & $\mathrm{F}$ & +++ & 1.31 & 1.93 & $\mathrm{~F}$ & +++ & 1.24 & 1.78 \\
\hline Cucumber peel & $\mathrm{F}$ & ++ & 0.67 & 1.03 & $\mathrm{~F}$ & ++ & 0.70 & 0.78 \\
\hline Potato peel & $\mathrm{F}$ & ++ & 1.16 & 1.37 & $\mathrm{~F}$ & +++ & 1.05 & 1.21 \\
\hline Brinjal peel & $\mathrm{F}$ & +++ & 1.05 & 1.26 & $\mathrm{~F}$ & +++ & 0.91 & 1.11 \\
\hline Banana peel & $\mathrm{F}$ & +++ & 1.22 & 1.82 & $\mathrm{~F}$ & +++ & 1.19 & 1.78 \\
\hline Papaya Peel & $\mathrm{F}$ & +++ & 1.34 & 1.97 & $\mathrm{~F}$ & +++ & 1.30 & 1.79 \\
\hline Radish waste & $\mathrm{M}$ & ++ & 0.68 & 0.84 & M & ++ & 0.46 & 0.69 \\
\hline Cabbage waste & $\mathrm{F}$ & +++ & 0.98 & 1.31 & $\mathrm{~F}$ & +++ & 1.09 & 1.11 \\
\hline FYM & S & + & 0.27 & 0.32 & $\mathrm{~S}$ & + & 0.16 & 0.19 \\
\hline Poultry & $\mathrm{S}$ & + & 0.26 & 0.27 & $\mathrm{~S}$ & + & 0.13 & 0.16 \\
\hline Guava waste & $\mathrm{F}$ & +++ & 1.08 & 1.97 & $\mathrm{~F}$ & +++ & 1.05 & 1.09 \\
\hline Spinach waste & $\mathrm{F}$ & +++ & 1.23 & 1.24 & $\mathrm{~F}$ & +++ & 1.06 & 1.07 \\
\hline Orange peel & $\mathrm{F}$ & +++ & 0.93 & 1.04 & $\mathrm{~F}$ & +++ & 0.72 & 0.81 \\
\hline Sugarecane waste & $\mathrm{F}$ & +++ & 1.21 & 1.67 & $\mathrm{~F}$ & +++ & 1.21 & 1.87 \\
\hline Used tea leaves & $\mathrm{F}$ & +++ & 1.01 & 1.54 & $\mathrm{~F}$ & +++ & 0.91 & 0.97 \\
\hline Pea husk & $\mathrm{F}$ & +++ & 1.82 & 1.89 & $\mathrm{~F}$ & +++ & 0.83 & 0.84 \\
\hline Rice husk & $\mathrm{S}$ & + & 0.20 & 0.41 & $\mathrm{~S}$ & + & 0.23 & 0.37 \\
\hline Wheat bran & M & ++ & 0.79 & 0.83 & M & ++ & 0.81 & 0.84 \\
\hline
\end{tabular}

$+\quad=$ Slow growth

$++=$ Moderate $(\mathrm{M})$

$+++=$ Aboundant (Fast)

$\mathrm{F} \quad=$ Fast

$\mathrm{M}=$ Mediation

$\mathrm{GR}=$ Growth rate

$\mathrm{SP}=$ Sporulation pattern 